\title{
Arbitration Proceedings Involving State Entities/Public Institutions in Nigeria: How to Prevail Public Interest Using the Dispute Between Statoil and Texaco Against the Nigerian National Petroleum Corporation as a Case Study.
}

\author{
Ofekeze Okiemute Darlynton ${ }^{1}$
}

\begin{abstract}
:
This work is intended to highlight the inadequacy of the present Nigerian Arbitration laws in arbitrations involving the Government and private organizations particularly in relation to the issue of public interest. The works also proffers solutions on how public interest can be protected in arbitrations involving the Government and private organizations.
\end{abstract}

\section{Introduction:}

In Nigeria there has been an increase in Arbitrations involving Private and State/Public Institutions. This is due to increased business interactions between the government and private entities largely due to the outsourcing of traditional government functions to private organizations or collaboration between government and private organization to perform a governmental obligation. In some instance, it is the intervention of Government in a commercial sector particularly where such sector has so much impact on the life and welfare of citizens.

On the other hand, there has been a growing attraction for arbitration as a better means of dispute resolution arising from commercial transactions. Arbitration as a means of resolving disputes is a private arrangement built around a fundamental principle of party autonomy. In Nigeria, the Arbitration and Conciliation Act is the relevant law guiding Arbitration Proceedings.

The present operation of Nigerian Arbitration laws did not obviously envisage arbitrations involving public institutions as it is built around commercial and private law theories and the broad issue of public interest is not given consideration. This has in certain cases created situations where public interest comes in conflict with private interest of parties.

It is this issue of public interest in arbitration involving state or state-owned entities that this work intends to address.

1 Managing Partner, Onyx \& Bricks (Barristers and Solicitors), a General Service Law Firm in Nigeria.dofekeze@onyxandbricks.com. 


\section{Arbitration}

In simple terms, Arbitration is the private judicial determination of disputes by an independent third party or parties. The essential characteristics of an arbitration incudes; it is private in nature, it is voluntary and confidential, and at first glance may give the impression of an institution less "endowed" with strict rules of substantive and procedural law. Also, parties are free to choose or even develop rules that may constitute an arbitration proceeding, become compulsory for the parties and arbitrators, respected and applied by them. ${ }^{2}$

\section{State/Public Institutions}

As Georges Burdeau famously observed, although nobody has ever seen the State, it is not something unheard of and in this sense is not a pure fiction. Similarly, a lawyer might point out that the reverse is also true: while the State may be considered a social reality, it is also a legal fiction - a legal entity vested with legal rights and obligations. Indeed, one might say that it is the challenge of translating the State's legal rights and obligations into a social reality is what law - in particular international and constitutional law - is all about ${ }^{3}$.

In other words, the State is an artificial person with so much responsibility and powers. State owned or public institutions are those whose powers of functionality are derived from the state. It also includes those who perform public functions.

\section{Public Interest}

Public interest is always used in context; therefore, it is not easy to properly define the concept of public interest. V. Held in his book "The Public Interest and Individual Interest" suggested three types of approaches to defining public interest: common interest theories, preponderance theories and unitary conceptions.

According to V. Held, Common interest theories are based on the hypothetical existence of interests' common to all members of society, while preponderance theories look to a majority of interests. Common and preponderance interest theories thus tend to conceptualize public interest on a majoritarian basis. On the other hand, the unitary conception takes a normative approach and places emphasis on what ought to be in the public interest from a social welfare viewpoint.

While a crude conception of democracy would favour a majoritarian approach to public interest, in a system displaying constitutional features, the public interest can, and should, be directed towards serving fundamental constitutional values, including values reflecting minority interests ${ }^{4}$

2 . Diana Loredana Hogas, Principle of Law Applicable to Arbitration Proceedings http://tribunajuridi ca.eu/arhiva/An4v 2/10\%20Hogas.pdf.

3 GEORGES BURDEAU, L'ETAT (Paris: Seuil, 1970), p. 13.)

4 A. Kulick, Global Public Interest in International Investment Law (New York, Press 2012) 151-152. 
The English Law subscribes to an inclusive definition of public interest as a set of interests reflecting the minimal value structure underpinning society, as these values are shaped by constitutional and administrative law principles, and democratic institutions and traditions. $^{5}$

This English Law approach reveals the core meaning of public interest in considering disputes under public private contracts. With this in mind, where a contract between a public body and private organization touches on the economy and social policy, it then becomes public interest. For example, the allocation of scarce government resources to fund the cost of government contracts for the provision of public infrastructure will certainty impact the economy.

The Nigeria Land Use Act makes reference to the concept of Public Interest in government compulsorily acquiring lands. The case laws which gives interpretation to this concept of Public Interest under the Land Use Act are suggestive that the concept of Public Interest is not necessarily one which is common to the general public but any interest which falls within the responsibility of government to either provide or protect.

\section{Public Interest and The Fundamentals of Arbitration}

In Nigeria, the Arbitration and Conciliation Act 2004 (ACA) and the Arbitration Rules made pursuant to the ACA governs arbitration and its proceedings. Section 2 of the ACA provides that "Unless a contrary intention is expressed therein, an arbitration agreement shall be irrevocable except by the agreement of parties or leave of court or judge".

Also, Article 47(1) of the Arbitration Rules state that: "the arbitral tribunal shall decide the dispute in accordance with the rule in force in the country whose laws the parties have chosen as applicable to the substance of the dispute".

Clearly, one of the fundamentals of Arbitration in Nigeria is Party Autonomy. The Nigerian Law allows parties to choose the applicable law to their transaction. Again, Section 47(4) of the ACA makes it clear that the tribunal shall not decide ex aequo et bono (i.e what is just and fair or according to good conscience) or amiable compositeur (i.e act as mediator), unless the parties have expressly authorized it to do so.

Furthermore, in Section 47(5) of the ACA, it is clear that in all cases, the arbitral tribunal shall decide in accordance with the terms of the contract and shall take into account the usages of the trade applicable to the transaction. Apart from the above provisions, the Nigeria Arbitration Act, in recognition of the principle of party autonomy further confers on parties the freedom to resolve by agreement the number of arbitrators and their appointment, place of arbitration and language to be used in arbitral proceedings. The freedom to choose the applicable law is very fundamental; the reason being that the dispute will be decided in

5 S.M King, B.S Chilton and G.E Roberts, 'Reflections on Defining the Public Interest' (20100 41 Administration \& Society, 958. 
accordance with the law chosen by parties, since the parties are bound by the law that they have chosen.

Arbitration proceedings are usually confidential in nature. This is one of the attractions for corporations. Its proceedings are not open to $3^{\text {rd }}$ parties. An arbitral panel is also not ordinarily bound by judicial precedents. They may decide to review other awards to provide guides but the doctrine of judicial precedents is not mandatorily applicable in Arbitration proceedings.

The foregoing fundamentals of party autonomy, confidentiality and non-applicability of precedents often contrast with the issue of public interest. An arbitration involving the state might require an Arbitral Panel to interpret statutes which is a role that falls squarely on the Judiciary which is an arm of government. Sometimes, these statues have been given judicial interpretation which the Panel is not bound to follow. Settlement of disputes in Arbitration are largely treated on a case by case basis.

Once public interest is involved, the interested parties become numerous. The persons whose interest will be affected exceeds the named parties to the arbitration agreement. Often times, the media, politicians, interest groups, legislators, supervising ministries and several others have a genuine interest in following and knowing the outcome of arbitration proceedings.

The sovereignty of a state is exposed when private persons are left with the powers to decide on matters which have overwhelming impact of citizens. Unlike, the Courts which endeavor to have a public policy consideration in reaching a decision. The Arbitration process is structured towards protection of private interest.

\section{CASE STUDY}

\section{STATOIL (NIGERIA) LIMITED \& ANOR v. FEDERAL INLAND REVENUE} SERVICE \& ANOR

\section{(2014) LPELR 23144 (CA)}

In the Instant case, Statoil (Nigeria) Limited and Texaco Nigeria Outer Shelf Company Limited had initiated an arbitration proceeding against the Nigeria National Petroleum Corporation (NNPC) in respect of oil acreages under a Production Sharing Contract (PSC). The reliefs sought by Statoil and Texaco were basically on the applicable royalty rate to be remitted, the Petroleum Profit Tax (PPT) returns to be used to allocate Tax Oil and the accurate computation of PPT and investment tax credit.

The Federal Inland Revenue Services (FIRS) during the pendency of that arbitration then took out an originating summons against NNPC, Statoil and Texaco seeking determination of the following questions;

1. Whether the Arbitral Tribunal in the Matter of Arbitration between (1) Statoil ((Nigeria) Limited (2) Texaco Nigeria Outer Shelf Limited AND Nigeria National Petroleum Corporation, has jurisdiction to determine the subject matter of the arbitration which deals with taxation of the defendants by the Federal Inland Revenue Service, 
which jurisdiction is conferred on the Federal High Court by Section 251 of the Constitution of the Federal Republic of Nigeria, 1999 as amended.

2. Whether the Arbitral Tribunal has jurisdiction to enter a valid award on the taxation of the defendants which will have a binding effect on the plaintiff in the interpretation, application and administration of the Petroleum Profit Tax Act and the Deep Offshore Act, Education Tax Act, and Company Income Tax Act, and any other statute for the time being in force in Nigeria, as to entitle the plaintiff to seek reliefs being sought in this suit.

3. Whether upon a proper reading of Section 251(1)(n) of the Constitution of the Federal Republic of Nigeria, 1999 (as amended) the questions in dispute raised regarding the operation of Production Sharing Contract the subject matter of dispute between parties therein is not within the exclusive jurisdiction of the Federal High Court and thereby rendering the entire purported arbitral proceedings unconstitutional, null and void ab initio."

The reliefs sought by the FIRS were as follows;

"1. A declaration that the claim of the 2nd and 3rd defendants touching on taxation upon which reference has been made to arbitration is not one which is allowed by law to be settled by Arbitration.

2. A declaration that the determination or claim by way of award before the said Arbitration will impinge on the right of the plaintiff/applicant to assess and collect tax and generate revenue for the Federal Government of Nigeria.

3. A declaration that the reference to the claim of the other defendants against the 1st defendant upon which terms reference has been made to Arbitration is contrary to public policy.

4. An order in addition to, or in alternative to (2) above revoking the Arbitration clause in so far as it relates to taxation or in the alternative an order excluding taxation and matters related thereto from the ambit of the arbitration agreement between the defendants.

5. An order restraining the defendants, by themselves, servants, agents, or counsel from continuing with, or purporting to take any benefit from or abiding by any obligations or rights no matter howsoever described or arising from the arbitral proceedings or awards made pursuant thereto.

6. A declaration that the arbitration provisions in the Production Sharing Contract and the defendants' submission to an arbitration on matters exclusively reserved for the Federal High Court is unconstitutional, null, void and of no effect."

Statoil and Texaco filed a preliminary objection where they argued three issues.

1. FIRS was not a party to the PSC and therefore has no locus standi to sue on issues bordering on it.

2. The suit was an abuse of court process. 
3. The suit is in violation of Section 34 of the Arbitration and Reconciliation Act which limits the instances in which a Court can intervene in matters governed by the Act.

The High Court dismissed the Preliminary objection. Statoil and Texaco then appealed to the Court of Appeal.

Interestingly, in arguing that the suit was an abuse of court process, Statoil and Texaco contended that the suit was a collusion between NNPC and FIRS who is not a party to the PSC. When FIRS argued that collusion has not been proved by Statoil and Texaco, they in their reply argument argued that the Arbitration process is a confidential one, hence the court should infer collusion.

On the issue of FIRS's locus standi to sue, the Court made recourse to the Federal Inland Revenue Service Act of 2007 and held that its right to sue on taxation related issues was obtainable from the Act.

The Court dismissed the preliminary objection. Statoil and Texaco have now appealed to the Supreme Court.

The foregoing case brings the bare the inability of an arbitration agreement, law, procedure to effectively cater for a public interest issue. In other sense, the case shows the audacity of an arbitration arrangement to interfere with existing public law made for public interest.

\section{Conclusion}

Arbitrations involving public institutions will always bring to bare public interest issue or conflict between arbitration agreement and public law. It is therefore important that our Arbitration laws and procedures are reviewed to bring a distinction between purely commercial arbitrations and arbitrations involving public institutions.

While purely commercial arbitrations can be governed by the strict principles of party autonomy and other arbitration fundamentals, arbitrations involving public institutions should allow for more judicial interference before, during and after the arbitration. The law should allow for reference to the Court by the Arbitration tribunal issues that border on public law and public interest as the Judges are better placed to consider public interest issues.

The Arbitration laws and procedure should be reviewed to water down the confidentiality principle. Arbitration proceedings involving public institutions should be made public and its documentations should be assessible by members of the public.

\section{Bibliography}

Arbitration and Conciliation Act, Cap A24, LFN, 2004

A. Kulick, Global Public Interest in International Investment Law (New York, Press 2012)

Diana Loredana Hogas, Principle of Law Applicable to Arbitration Proceedings http://tribunajuridica.e u/arhiva/An4v 2/10\%20Hogas. 
Stavros Brekoulakis, Margaret Devancy, https://onlinelibrary.wiley.com/doi/abs/10.1111/1468-2230.12 241 (Last assessed on 28/8/2019)

V. Heiskanen, State as a Private: The Participation of States in International Commercial Arbitration. http://www.transnational-dispute-management.com. TDM, Vol.7, Issue 1, April 2010.

S.M King, B.S Chilton and G.E Roberts, 'Reflections on Defining the Public Interest' (2010) 41 Administration \& Society 